\title{
ANALISIS PENGEMBANGAN ALAT EVALUASI PEMBELAJARAN BERBASIS INTRANET
}

\author{
Yunita Dwi Ermawati \\ Pendidikan Ekonomi, Jurusan Pendidikan Ekonomi, Fakultas Ekonomi, Universitas Negeri Surabaya, e-mail: \\ yunitaermawati@mhs.unesa.ac.id
}

\begin{abstract}
Riza Yonisa Kurniawan
Pendidikan Ekonomi, Jurusan Pendidikan Ekonomi, Fakultas Ekonomi, Universitas Negeri Surabaya, e-mail: rizakurniawan@unesa.ac.id
\end{abstract}

\begin{abstract}
Abstrak
Dalam pendidikan terdapat proses belajar, proses belajar tersebut terdapat peran guru dan siswa aktif untuk mencapai suatu tujuan yaitu keberhasilan belajar. Keberhasilan pada proses belajar dapat dilihat dari hasil belajar. Hasil belajar dapat ditunjukkan melalui evaluasi yang dilakukan oleh guru terhadap siswa. Kegiatan evaluasi pembelajaran diperlukannya konsep yang baik dan terarah sehingga mengukur hasil belajar siswa akan baik. Alat evaluasi pembelajaran merupakan suatu proses atau kegiatan, pengumpulan data, dan informasi yang memiliki banyak dimensi dalam rancangan program pembelajaran bersifat sistematis dan berkelanjutan yang dibuat oleh guru digunakan sebagai pertimbangan dasar membuat keputusan, menyusun kebijakan, maupun menyusun program pembelajaran mengenai keberhasilan siswa dalam pencapaian tujuan-tujuan pembelajaran. Alat evaluasi pembelajaran biasanya hanya berbentuk kertas (paper test). Tujuan Penelitian ini adalah untuk menganalisis hasil penelitian terdahulu terkait pengembangan alat evaluasi pembelajaran berbasis intranet. Metode yang digunakan adalah telaah pustaka (literature review) yaitu menjelaskan temuan-temuan terdahulu yang kemudian dianalisis dan disimpulkan sesuai pada tujuan penelitian. Hasil telaah penelitian terdahulu menunjukkan alat evaluasi pembelajaran berbasis intranet yang dikembangkan di kategorikan sangat layak, respon peserta didik menarik dan efektif digunakan untuk meningkatkan hasil belajar yang didapatkan melalui uji kelayakan kepada para ahli dan uji coba kepada peserta didik.
\end{abstract}

Kata Kunci : Alat evaluasi pembelajaran, Hasil belajar, Telaah pustaka

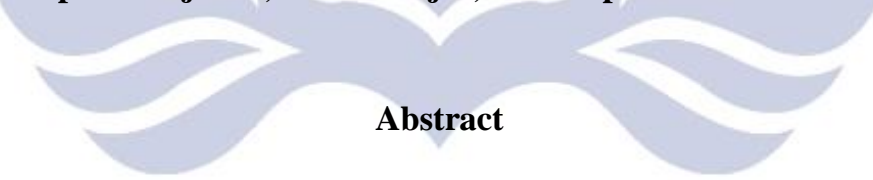

In education there is a learning process, the learning process there is an active role of teachers and students to achieve a goal that is learning success. Success in the learning process can be seen from the results of learning. Learning outcomes can be demonstrated through evaluations conducted by the teacher of students. Learning evaluation activities need good and directed concepts so that measuring student learning outcomes will be good. Learning evaluation tool is a process or activity, data collection, and information that has many dimensions in the design of learning programs that are systematic and ongoing made by the teacher used as a basic consideration for making decisions, formulating policies, and preparing learning programs about student success in achieving goals -learning objectives. Learning evaluation tools are usually only in the form of paper (paper test). The purpose of this study is to analyze the results of previous studies related to the development of intranet-based learning evaluation tools. The method used is literature review, which explains the previous findings which are then analyzed and concluded according to the purpose of the study. The results of previous research studies indicate that the intranet-based learning evaluation tools developed are categorized as very feasible, interesting and effective student responses are used to improve learning outcomes obtained through feasibility testing to experts and trials to students.

Keywords : Learning evaluation tools, Learning outcomes, Literature review

\section{PENDAHULUAN}

Dalam melakukan kegiatan evaluasi pembelajaran, guru memerlukan evaluasi yang baik dan terarah agar berjalan sebagaimana mestinya. Diperlukannya konsep yang baik dalam evaluasi pembelajaran. Konsep tersebut terdiri dari sasaran dalam evaluasi proses pembelajaran dan tahapan pelaksanaan evaluasi. Untukmengukur hasil belajar-siswa yang baik, dibutuhkan 
suatu alat ukur yang baik. Jika tidak maka informasi yang diperoleh tidak dapat dipercaya dan mungkin tidak memberikan gambaran yang sebenarnya tentang hasil belajar.

Konsep pada sasaran dalam evaluasi pembelajaran ditunjukan pada pelaksanaan dan pengelolaan pembelajaran. Sedangkan konsep pada tahapan pelaksana evaluasi proses pembelajaran adalah penentuan tujuan, menentukan desain evaluasi, pengembangan instrumen evaluasi, pengumpulan informasi data, analisis dan intrepentasi dan tindak lanjut. Selain membutuhkan konsep evaluasi yang baik juga memiliki prinsip dan alat sebagai hal yang penting dalam pencapaian pembelajaran pada, Arikunto (2013). Prinsip evaluasi memiliki hubungan tiga komponen yang sangat erat yaitu tujuan pembelajaran, kegiatan pembelajaran atau KBM, dan evaluasi. Alat evaluasi dikatakan baik apabila-mampu mengevaluasi sesuatu dengan hasil seperti keadaan yang dievaluasi. Menurut Arikunto, (2013) teknik alat evaluasi dapat berupa teknik nontes dan teknik tes.

Pada umumnya tes yang dibuatkan oleh guru untuk melakukan evaluasi pembelajarana kepada siswanya berupa tes subjektif maupun tes objektif. Menurut, Widoyoko (2016) Tes uraian (esai) adalah butiran soal yang mengandung pertanyaan atau tugas yang jawaban atau pengerjaan soal tersebut harus dilakukan dengan cara mengekspresikan pikiran.peserta tes. Sedangkan tes objektif yaitu tes yang,,dibuat sedemikian rupa sehingga hasil tes itu dapat dinilai secara objektif sehingga akan menghasilkan skor yang sama.

Berdasarkan, hasil observasi yang telah dilakukan oleh peneliti, siswa kelas XII masih menggunakan media kertas dalam mengerjakan ujian. Sedangkan, Ujian Nasional Berbasis Komputer (UNBK) sudah digencarkan untuk meningkatkan mutu pendidikan dan mengurangi kecurangan dalam mencontek. Teknologi Informasi dan Komunikasi (TIK) memiliki peran penting,di bidang pendidikan, khususnya dalam proses pembelajaran. Salah satunya membuat alat evaluasi yang menarik dan tidak membosankan. Pengembangan alat evaluasi pembelajaran berbasis intranet sangat tepat sekali guna meningkatkan kualitas pembelajaran.

Berdasarkan uraian di atas, maka diperlukan adanya analisis yang dapat menunjukkan bahwa alat evalausi pembelajaran dikembangkan dengan memperhatikan kelayakannya, respon peserta didik setelah menggunakan alat evalauasi pembelajaran. Oleh karena itu, peneliti mengambil judul "Analiasis Alat Evaluasi Pembelajaran Berbasis Intranet" yang bertujuan untuk menganalisis hasil penelitian terdahulu terkait alat evalausi pembelajaran berbasis intranet.

\section{METODE}

Metode yang digunakan dalam penelitian ini adalah telaah pustaka yakni menganalisis temuan yang telah ada kemudian disimpulkan sesuai dengan analisis alat evalauasi pembelajaran berbasis intranet.

\section{HASIL DAN PEMBAHASAN}

\section{HASIL}

Hasil penelitian dari Rachmawati (2014) tentang "Pengembangan alat evaluasi pembelajaran berbasis komputer dengan Wondeshare Quiz Creator Pada Materi Pajak Penghasilan Pasal 21" dengan menggunakan metode model pengembangan 4-D dari Thiagarajan semmel dan semmel dalam Trianto (2015) yang telah dimodifikasi oleh peneliti. Tahap-tahap tersebut yaitu pendefinisian (define), tahap perancangan (design), tahap pengembangan (develop), dan tahap penyebaran (dessiminate) memperoleh hasil bahwa alat evalausi pembelajaran berbasis komputer efektif dan menarik digunakan dalam pembelajaran, untuk dapat memperoleh alat evaluasi yang efektif dan menarik terdapat instrumen yang digunakan dalam penelituan ini adalah lemar penilaian kelayakan ahli materi, ahli evaluasi, analisis butir soal dan angket respon siswa.Analisis data dalam penelitian ini menggunakan skala penilaian. Hasil validasi dari para ahli memperoleh nilai rata-rata persentase sebesar $80 \%$. Butir soal yang telah dianalisis kemudian diujicobakan kepada siswa dan mendapatkan persentase respon siswa sebesar $85,63 \%$ dengan kriteria sangat layak, didukung oleh hasil pengamatan aktivitas siswa selama uji coba mendapatkan persentase sebesar $80 \%$ dengan kriteria baik. Hasil keseluruhan validasi dari para ahli dan uji coba terbatas (pengguna) memperoleh nilai rata-rata persentase sebesar $85,43 \%$. Sehingga dapat disimpulkan bahwa alat evaluasi pembelajaran yang dikembangkan oleh peneliti dinyatakan sangat layak dan dapat di uji cobakan kepada peserta didik.

Hasil penelitian dari Putra (2013) tentang "Desain Dan Implementasi Evaluasi Pembelajaran Berbasis Multimedia Menggunakan Flash, Php Dan Mysql" yang menggunakan Metode dalam penelitian ini adalah Multimedia Development Life Cycle yang memiliki enam tahap yaitu: concept, design, obtaining content material, assembly, testing dan distribution. Memperoleh hasil bahwa model evaluasi pembelajaran efektif digunakan untuk meningkatkan hasil belajar peserta didik. Evaluasi pembelajaran Berbasis Multimedia Menggunakan Flash, Php Dan Mysql dikatakan efektif Penggunaan basisdata MySQL dalam penelitian ini sebagai media penyimpanan seluruh soal dan jawabannya serta nilai/skor yang diperoleh oleh 
mahasiswa. Flash sebagai interface dinamis untuk aplikasi server. Script PHP digunakan untuk menghubungkan aplikasi Flash movie dengan basisdata MySQL. Menggunakan Flash sebagai front-end, data dan variabel dapat dilewatkan antara basisdata MySQL, PHP, dan Flash untuk meningkatkan fungsi halaman yang menampilkan ujian dan pengelolaan basisdata.

Hasil penelitian dari Zahara (2015) tentang "Evaluasi Pembelajaran Online Berbasis Web Sebagai Alat Ukur Hasil Belajar Siswa Pada Materi Dunia Tumbuhan Kelas X Man Model Banda Aceh" yang menggunakan Metode dalam penelitian ini adalah metode penelitian pengembangan. Memperoleh hasil bahwa model evaluasi pembelajaran online berbasis web dapat dikembangkan dan diimplementasikan sebagai alat ukur hasil belajar materi dunia tumbuhan. Pengumpulan data dilakukan dengan memberikan tes evaluasi online bertahap dengan materi berbeda bryophyta, pteridophyta dan spermatophyta, tes hasil belajar dan pemberian angket. Data dianalisis secara deskriptif dengan melihat perkembangan nilai evaluasi online siswa dan data angket yang telah diberikan.

\section{PEMBAHASAN}

Berdasarkan hasil telaah penelitian terdahulu, dalam mengembangkan alat evaluasi pembelajaran terdapat moodel pengembangan. Model pengembangan berisi tahapan-tahapan yang dilalui dalam pembuatan alat evaluasi pembelajaran yang disesuaikan dengan karakterisitik materi yang dikembangkan, tahapan mencakup analisis butir soal disesuaikan dengan kurikulum yang berlaku, penginputan soal dalam alat evaluasi intranet, hingga uji coba modul kepada peserta didik. Terdapat banyak model pengembangan yang bisa digunakan, Rachmawati (2014) menggunakan model pengembangan 4-D dari Thiagarajan semmel dan semmel yang terdiri atas Tahap-tahap yaitu pendefinisian (define), tahap perancangan (design), tahap pengembangan (develop), dan tahap penyebaran (dessiminate). Pada penilitian Putra (2013) dalam pengembangannya menggunakan Metode dalam penelitian ini adalah Multimedia Development Life Cycle yang memiliki enam tahap yaitu: concept, design, obtaining content material, assembly, testing dan distribution. Sedangkan pada penelitian Zahara (2015) menggunakan Metode dalam penelitian ini adalah metode penelitian pengembangan.

Untuk memperoleh kelayakan alat evaluasi pembelajaran, peneliti melakukan pengumpulan data penelitian baik angket terbuka yang digunakan bagi angket telaah materi dan angket tertutup dugunakan untuk angket validasi ahli meteri. Adapun masukan maupun saran yang diperlukan dari para ahli materi, ahli media, serta respon siswa sebagai penunjang pembuatan alat evaluasi pembelajaran berbasis intranet. Hal ini sesuai dengan Widasari dan Soesatyo (2017) pada penelitiannya mengenai "pengembangan media game ular tangga" bahwa Kelayakan media pembelajaran diperoleh dari hasil validasi media oleh ahli materi, dan ahli media. Hasil angket tersebut kemudian dianalisis dengan membagi skor total dengan skor maksimal dikali 100\% (Riduwan, 2016: 15).

Apabila alat evaluasi pembelajaran belum memenuhi kelayakan pada aspek materi, aspek konstruksi, aspek bahasa yang terdapat pada instrumen ahli materi, dan aspek keterbacaan, aspek penggunaan, aspek kualitas tampilan, aspek ruang yang terdapat pada instrumen ahli media, serta aspek tampilan, aspek penyajian materi, aspek manfaat yang terdapat pada instrumen respon siswa sehingga alat evaluasi pembelajaran tersebut mendapatkan kategori layak atau sangat layak untuk digunakan peserta didik dalam evaluasi pembelajaran. Hal ini sesuai dengan penelitian Permana (2015) tentang pengembangan Model Pembelajaran Berbasis Masalah Menggunakan Software Macromedia Flash 8 bahwa model pembelajarannya yang dikembangkan mendapatkan hasil kelayakan sebesar 90,42\% sehingga bahwa instrumen penelitian dikatakan sangat layak dari aspek instrumen ahli materi, instrumen ahli media, dan intrumen respon siswa.

Setelah mendapatkan kelayakan dari para ahli materi dan para ahli media dengan kategori layak atau sangat layak, maka modul diuji cobakan kepada peserta didik untuk mengetahui respon peserta didik, hal ini sesuai dengan penelitian Mustika (2014) tentang "pengembangan media mini book sebagai pembelajaran ekonomi" bahwa uji coba dilakukan untuk mendapatkan respon peserta didik mengenai produk yang dikembangkan.

Kemudian untuk mendapatkan alat evaluasi pembelajaran yang efektif digunakan uji coba validasi dan uji coba terbatas sesuai dengan penelitian Rachmawati (2014) bahwa alat evaluasi pembelajaran yang dikembnagkan efektif untuk digunakan pada saat evaluasi pembelajaran berbasis website.

\section{PENUTUP}

\section{Simpulan}

Berdasakan telaah kepustakaan dapat disimpulkan bahwa alat evaluasi pembelajaran yang dikembangkan memiliki kelayakan dengan katagori yang sangat layak, dan efektif. Dalam mencapai kelayakan dan keefektifan tersebut diperlukan sebuah model pengembangan, uji kelayakan kepada para ahli materi dan ahli media mengenai aspek materi, aspek konstruksi, aspek bahasa 
yang terdapat pada instrumen ahli materi, dan aspek keterbacaan, aspek penggunaan, aspek kualitas tampilan, aspek ruang yang terdapat pada instrumen ahli media dan kemudian uji coba kepada peserta didik untuk mengetahui respon peserta didik yang terdapat aspek tampilan, aspek penyajian materi, aspek manfaat yang terdapat pada instrumen respon siswa.

\section{Saran}

Berdasarkan simpulan di atas, saran yang dapat diberikan yaitu perlunya pengembangan alat evaluasi pembelajaran dengan menggunakan sistem online yang disesuaikan dengan kondisi yang dibutuhkan oleh peserta didik sehingga mudah diakses dimana-mana dan lebih meudah dipengerjaanya.

\section{DAFTAR PUSTAKA}

Arikunto, Suharsimi. 2013. Dasar-dasar Evaluasi Pendidikan. Jakarta: PT. Bumi Aksara.

Mustika, D. A. dan Kurniawan, R. Y. 2014. Pengembangan Media Mini Book Sebagai Media Pembelajaran Ekonomi Materi Pasar Dan Terbentuknya Harga Pasar Dalam Perkonomian untuk SMA/MA Kelas X. Jurnal Pendidikan Ekonomi (JUPE), 7(1).

Permana, G. Dan Haryudo, S. I. 2015. Pengembangan model pembelajaran berbasis masalah menggunakan software macromedia flash 8 pada mata pelajaran instalasi penerangan listrik untuk meningkatkan hasil belajar peserta didik di kelas XI TIPTL SMK Negeri 1 Nganjuk. Jurnal Pendidikan Teknik Elektro (JPTE), 4(3).

Putra, Syahrizal Dwi 2013. Desain Dan Implementasi Evaluasi Pembelajaran Berbasis Multimedia Menggunakan Flash, Php Dan Mysql. Jurnal Manajemen Informatika, 4(4).

Rachmawati, E. Dan Listyadi, A. 2014. Pengembangan Alat Evaluasi Pembelajaran Berbasis Komputer Dengan Wondeshare Quiz Creator Pada Materi Pajak Penghasilan Pasal 21. Jurnal Pendidikan Akuntansi (JPAK), 2(2).

Trianto, Ibnu Badar Al-Tabany. 2015. Mendesain Model Pembelajaran Inovatif, Progresif, dan Kontekstual. Jakarta: Kencana Prenada Group. Widasari, D. O. dan Soesatyo, Y. 2018. Pengembangan Media Game Ular Tangga Ekonomi Untuk Meningkatkan Minat Dan Hasil Belajar Siswa Pada Materi Kebijakan Moneter Dan Kebijakan Fiskal Kelas XI SMA Negeri 1 Driyorejo. Jurnal Pendidikan Ekonomi (JUPE), 6(1).
Widoyoko, S. Eko Putro. 2016. Evaluasi Program Pembelajaran. Yogyakarta: Pustaka Pelajar.

Zahara, Nurlia 2015. Evaluasi Pembelajaran Online Berbasis Web Sebagai Alat Ukur Hasil Belajar Siswa Pada Materi Dunia Tumbuhan Kelas X MAN Model Banda Aceh. Jurnal Ar- Raniry (Prosiding Seminar Nasional Biotik), 2(1).

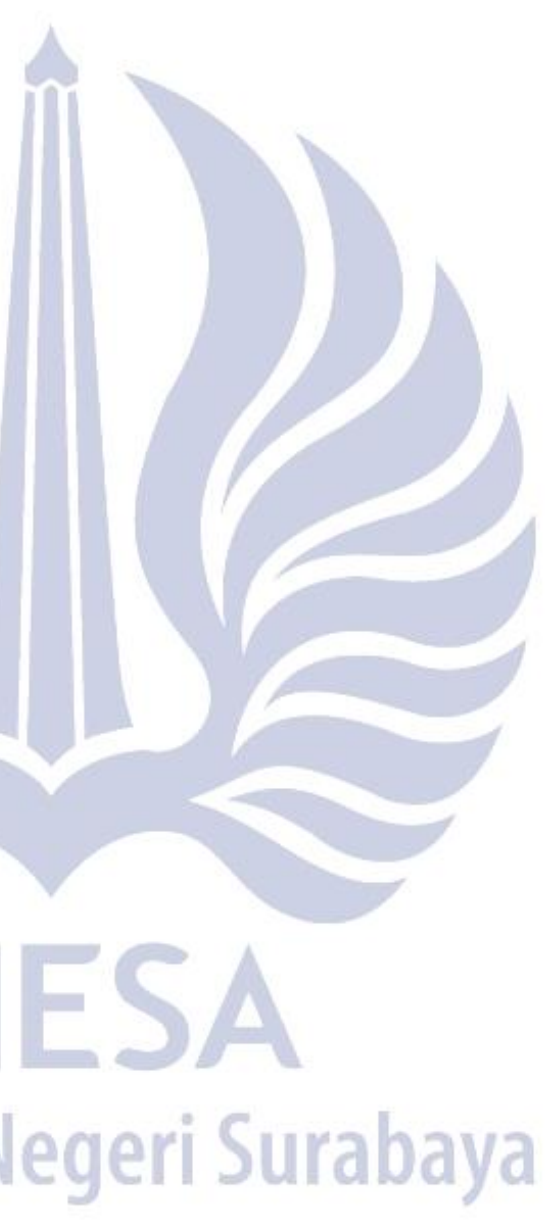

